\title{
An Afebrile and Severe COVID-19 Case That was Admitted Before the First Case Report in Our Country
}

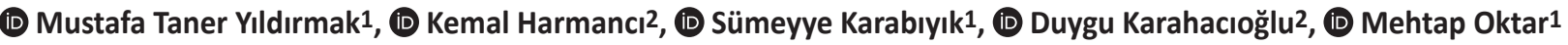

1 University of Health Sciences Turkey, Prof. Dr. Cemil Taş̧̧ığlu City Hospital, Clinic of Infectious Diseases and Clinical Microbiology, Istanbul, Turkey 2University of Health Sciences Turkey, Prof. Dr. Cemil Taşçığlu City Hospital, Clinic of Radiology, Istanbul, Turkey

\section{Abstract}

Typical symptoms in Coronavirus Disease-2019 (COVID-19) pneumonia are fever, cough and shortness of breath. These findings may not always coexist. Patients can apply with atypical or less common complaints. In the days when the disease had not been detected in our country, the diagnosis and treatment process of a COVID-19 case presenting with findings suggesting community-acquired lower respiratory disease is presented.

Keywords: COVID-19, afebrile, case, quantitative lung CT

\section{INTRODUCTION}

In the early stages of the Coronavirus Disease-2019 (COVID-19) pandemic, there were difficulties in detecting patients before a case report was made in a country. When epidemiological, clinical and laboratory data are not distinctive, patients may be overlooked or cannot be definitively diagnosed. If the patient is also a health worker, there is a risk that the disease will be transmitted to other employees and patients. In this context, the process experienced in a health worker who had been admitted and monitored on suspicion of atypical pneumonia will be discussed.

\section{CASE PRESENTATION}

\section{Case}

A 44-year-old female patient, whose complaints of weakness, anorexia, sweating, muscle joint pain and cough had started a week ago, was admitted on March 9, 2020 with a prediagnosis of lower respiratory tract infection. When examined three days ago, vital functions were found to be normal, crackles and increased density in the lower zones on Posteroanterior chest $X$-ray were observed. The infection parameters were as follows: White blood cell: 5.290/mm³, PNL: $64 \%$, and C-reactive protein (CRP): $9 \mathrm{mg} / \mathrm{L}$ (normal <5). Complaints of dry cough increased under outpatient clarithromycin $500 \mathrm{mg} 2 \times 1$ treatment. It was understood from the detailed anamnesis of the patient, who worked as a staff in our hospital's infectious diseases clinic, that her complaints had started four days after her relatives from the Netherlands attended the funeral ceremony held in Antalya. There was no feature in her family history, it was learned that she had no additional disease and she took no medication continuously. Examination findings revealed the followings: Fever: $36{ }^{\circ} \mathrm{C}$, pulse: $91 / \mathrm{min}$ rhythmic, respiratory rate: $18 / \mathrm{min}$ regular, diffuse crepitant rales in the middle lower zones in both hemithoraces. Other examination findings were normal. Piperacillin/tazobactam and oseltamavir were added to her treatment. Lung computed tomography (CT) was requested. One day later, the radiology clinic specialist verbally reported that CT findings were compatible with COVID-19. Diarrhea started on the $2^{\text {nd }}$ day of her hospitalization. No pathogen was detected in stool microscopy and culture. In the first CT scan, crazy-

Phone: +90 5312028136 E-mail: mtanery@gmail.com ORCID ID: orcid.org/0000-0001-7006-7161 
paving pattern characterized by diffuse patch-like ground-glass opacities and interlobular septal thickening were observed in all lobes of both lungs in the lower zones and peripheral areas suggesting a viral pneumonia. Due to progressive and unresolved clinical findings, it was rechecked with CT on the $3^{\text {rd }}$ and $15^{\text {th }}$ days of hospitalization. Hydroxychloroquine (Hq) $200 \mathrm{mg}$ tbl 2x1 and lopinavir/ritonavir (LPV/r) $200 \mathrm{mg}$ tbl $2 \times 2$ combined with nonspecific supportive therapy were initiated. Hq was given for 5 days and LPV/r for 14 days. She did not have any fever in the clinical course. On the $3^{\text {rd }}$ day of treatment, an increase in the density of the infiltration areas and the diffusion of ground glass opacities were observed on control CT. Figures $1 \mathrm{a}$ and b show the changes in lung parenchyma involvement during the disease process. Quantitative lung involvement volume was calculated. Total lung volume was 2932 cc, COVID-19 uptake volume was 665 cc, COVID-19/lung volume ratio was approximately $22.6 \%$ (Figures $2 \mathrm{a}$ and b). The mean density of the COVID-19 uptake area was calculated to be -285 hounsfild units (HU) (normal $-1000 \mathrm{HU})$.
The patient's complaints started to regress from the $7^{\text {th }}$ day of hospitalization. The most challenging clinical finding was severe cough and shortness of breath. Bloody sputum was observed for two days. Supportive treatment was continued by providing nasal oxygen support and hydration. Normal flora bacteria grew in sputum culture, mycobacteria were not detected. Influenza $\mathrm{A} / \mathrm{B}$ antigen was found negative in throat swab. Blood type was A Rh (-). Changes in the patient's specific laboratory values are shown in Table 1.

The patient was discharged on the $16^{\text {th }}$ day of hospitalization. Although her cough complaint decreased when she was discharged, it continued. The throat-nose swab polymerase chain reaction (PCR) test taken on the $9^{\text {th }}$ day of the complaints was found to be negative, and the rapid antibody test for immunoglobulin $\mathrm{G}(\mathrm{IgG})$ and $\mathrm{IgM}$ performed on the $17^{\text {th }}$ day was found to be strongly positive (Figure 3 ). The positivity of second PCR test performed on the $10^{\text {th }}$ day of her complaints was learned long after she was discharged, since the result of the test was delayed. Although the patient was a clinical staff, no illness
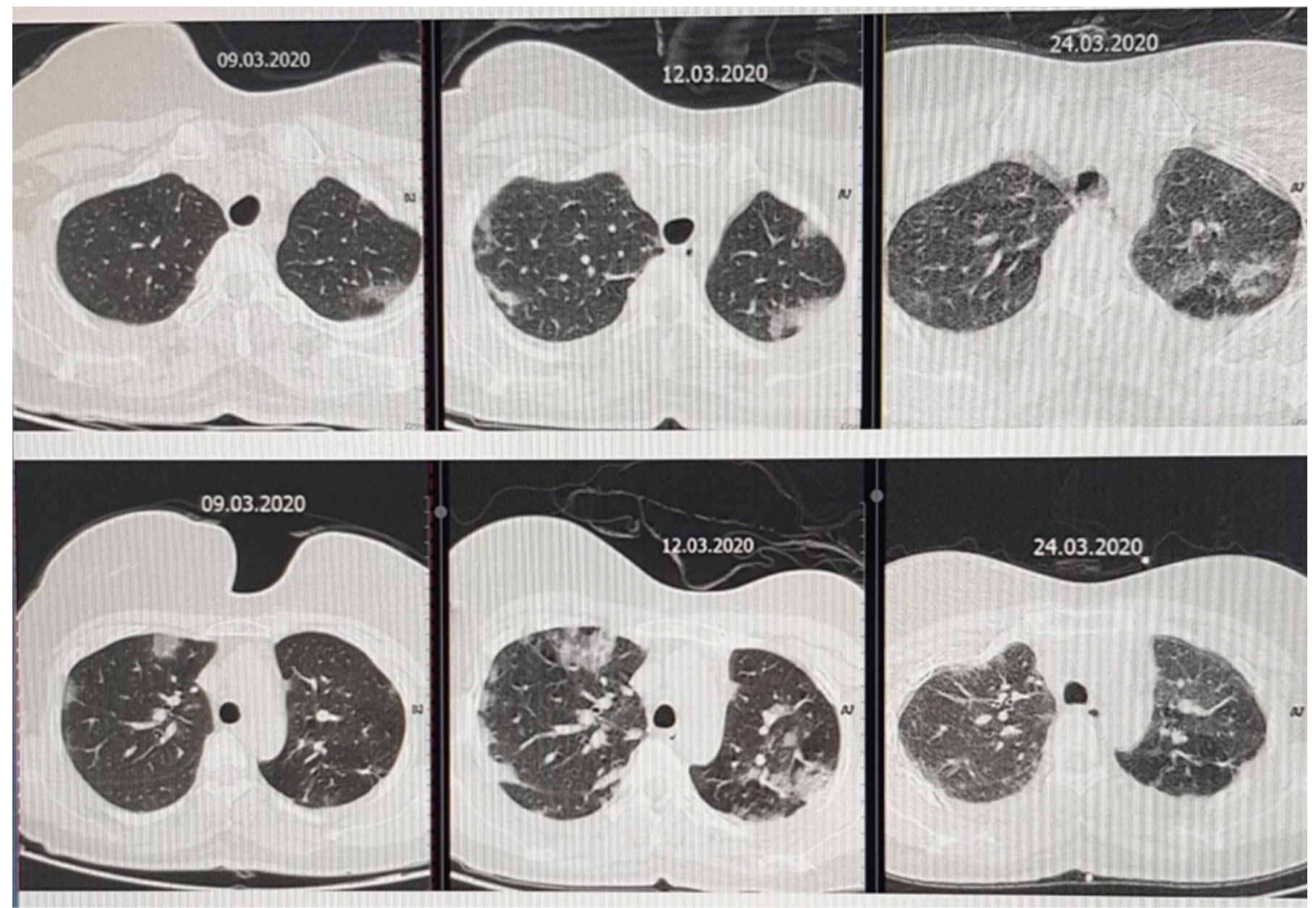

Figure 1a. Appearance of pneumonic involvement in different axial sections in lung CT performed at three different dates during the disease process CT: Computed tomography 


\begin{tabular}{|c|c|c|c|c|}
\hline Laboratory finding (normal range) & First admission (4th day*) & Hospitalization ( $7^{\text {th }}$ day) & Maximum value & Discharge $\left(2^{\text {th }}\right.$ day) \\
\hline WBC (3.8-10 103/uL) & 5.29 & 5.14 & 6.91 & 5.64 \\
\hline Lymphocyte (1.18-3.74 103/uL) & 1.17 & 1.44 & 2.40 & 2.09 \\
\hline $\mathrm{Hgb}(115-155 \mathrm{~g} / \mathrm{L})$ & 125 & 121 & 101 & 111 \\
\hline Platelet (150-400 103/uL) & 257 & 204 & 473 & 417 \\
\hline $\operatorname{CRP}(<5 \mathrm{mg} / \mathrm{L})$ & 9 & 88 & 148 & 3.5 \\
\hline Sedimentation $(1-15 \mathrm{~mm} / \mathrm{h})$ & & 37 & & \\
\hline Procakitonin $(<0.12 \mu \mathrm{g} / \mathrm{L})$ & & $<0.12$ & 2.6 & $<0.12$ \\
\hline D-dimer $(80-500 \mu \mathrm{g} / \mathrm{L})$ & & 797 & 5950 & 5950 \\
\hline Fibrinogen $(2-4 \mathrm{~g} / \mathrm{L})$ & & 3.87 & 3.61 & \\
\hline INR (08-1.2) & & 0.93 & 1.1 & \\
\hline LDH/ALT/AST $(<248 / 0-50 /<35 \mathrm{U} / \mathrm{L})$ & $188 / 36 / 31$ & $344 / 38 / 51$ & $450 / 61 / 51$ & $325 / 61 / 39$ \\
\hline Creatin Phosphokinase (CPK) (0-145 U/L) & 68 & 130 & 488 & 53 \\
\hline
\end{tabular}

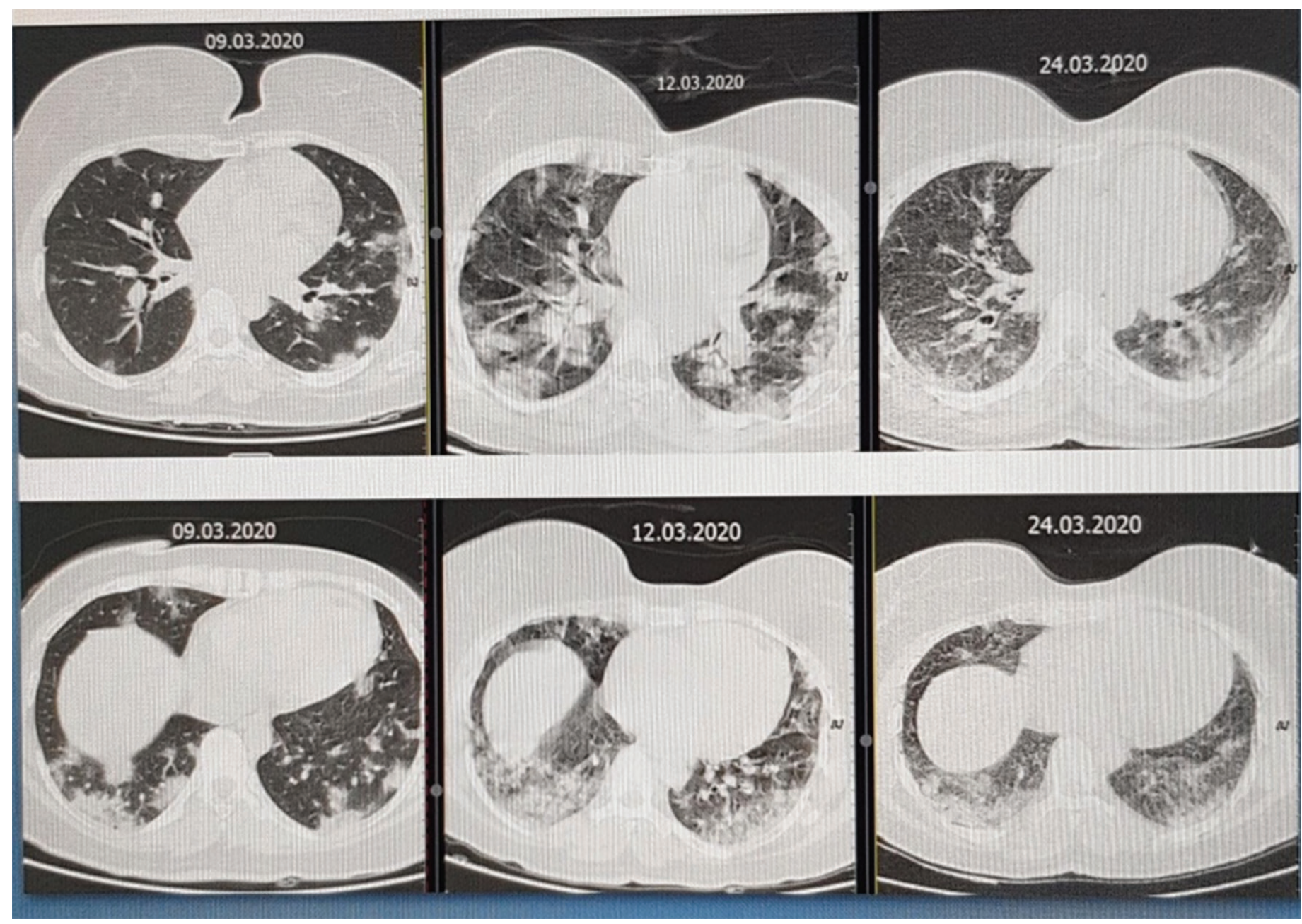

Figure 1b. Appearance of pneumonic involvement in different axial sections in lung CT performed at three different dates during the disease process СТ: Computed tomography 


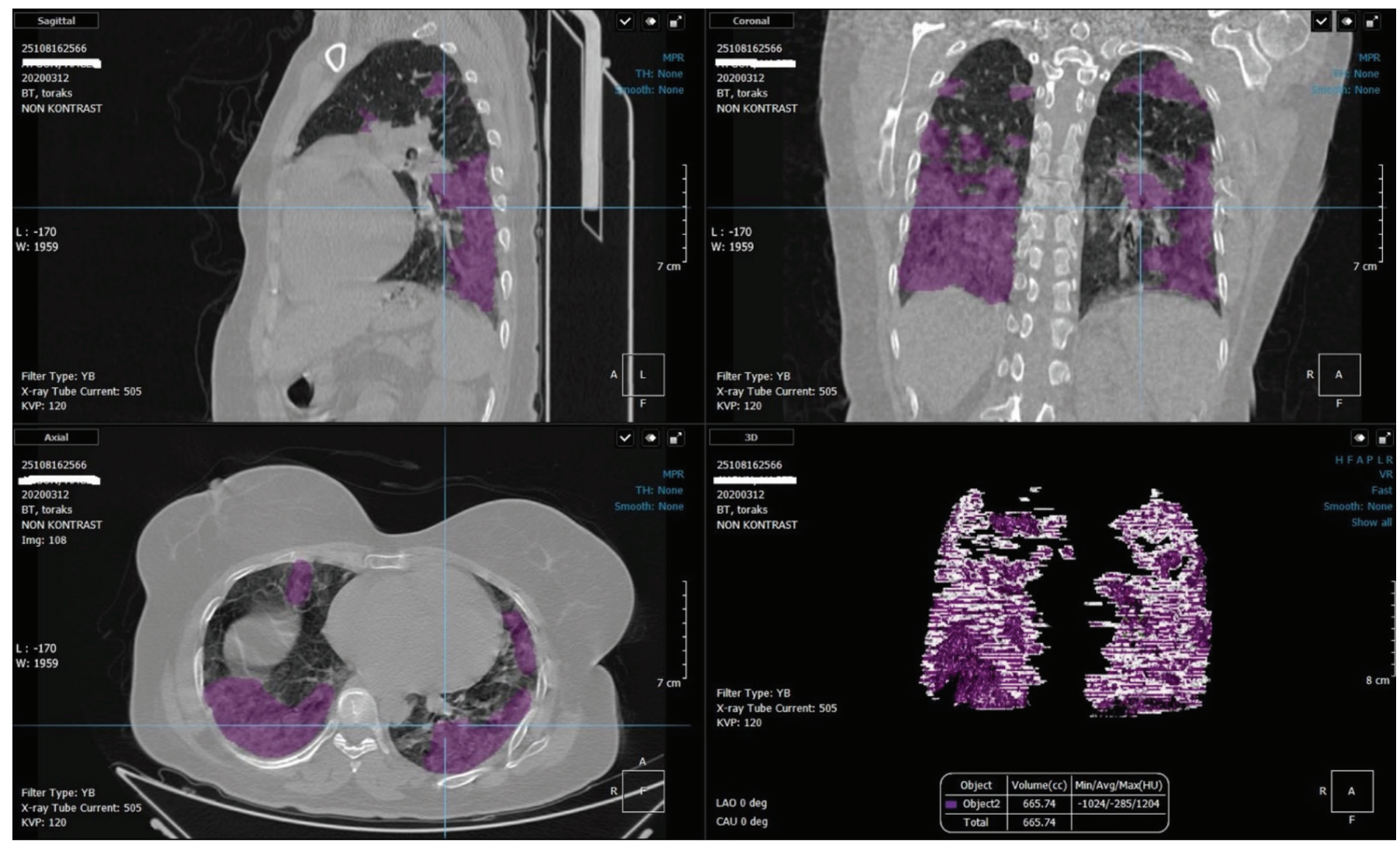

Figure 2a. Volumetric evaluation of areas affected by COVID-19 on lung CT shown in purple COVID-19: Coronavirus Disease-2019, CT: Computed tomography

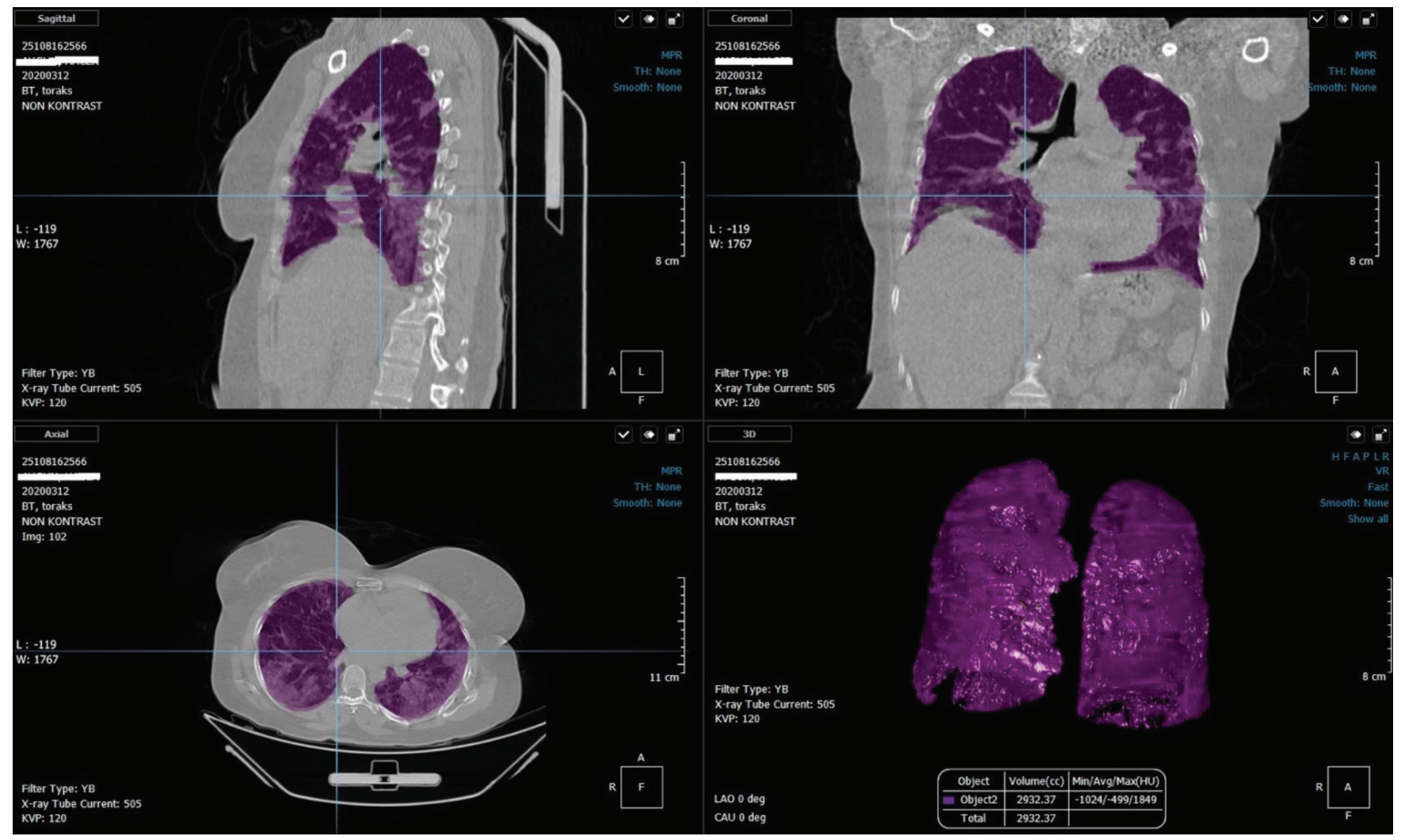

Figure $\mathbf{2 b}$. Color image of the patient's entire lung volume 


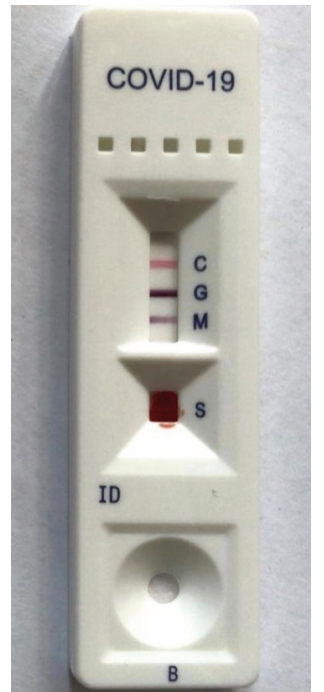

Figure 3. COVID-19 IgG and IgM positivity detected in the whole blood antibody test on the $17^{\text {th }}$ day of symptoms

COVID-19: Coronavirus Disease-2019, IgG: Immunoglobulin G, IgM: Immunoglobulin M

was found in other healthcare workers who worked together in the same environment, and her written consent was obtained from her for this case report.

\section{DISCUSSION}

Among the symptoms at first admission in patients with COVID-19, fever is detected at a rate of $43.8 \%$ and increases to $88.7 \%$ after hospitalization. Cough takes the second place with a rate of $67.8 \%$, and diarrhea may occur less frequently in 3.8\% (1). Our patient had a very severe and persistent cough, but body temperature was always found to be normal. In the laboratory tests, the most striking increase was seen in D-dimer, accompanying low fibrinogen was not detected. The mild lymphopenia observed at the beginning gradually returned to normal. The increase in CRP was remarkable, the increase in procalcitonin was mild and short-lived. During clinical follow-up, serum D-dimer, CRP, lactate dehydrogenase, and creatin phosphokinase values increased to levels of severe disease. At the first admission of the patient, COVID-19 was diagnosed due to the clinical findings as well as supportive lung CT findings. There is increasing data stating that quantitative measurement of pneumonia involvement volume and rate and pneumonia density in units of $\mathrm{HU}$ will have clinical prognostic value in patients with COVID-19 (2). In our patient, there was widespread involvement in the cross-sections in thorax CT findings in addition to persistent and severe clinical findings. Later, it was understood that the calculated volumetric involvement was low at $22.6 \%$ and the mean
$\mathrm{HU}$ value of the pneumonic areas was not at the level of severe pneumonic score. The patient's first Severe Acute Respiratory syndrome-coronavirus-2 PCR test was negative. In addition to the positive rapid antibody test, the diagnosis was confirmed by excluding other reasons. Although PCR is deemed necessary in the definitive diagnosis of COVID-19, it is known that it is not always sufficient on its own and does not rule out the disease. Antibody tests taken at the appropriate period are supportive of the diagnosis (3). The sensitivity and specificity of the rapid diagnostic antibody test (Healgen ${ }^{\circledR}$ ) we used were predicted to be $97.2 \%$ and $100 \%$ for $\operatorname{lgG}, 87.9 \%$ and $100 \%$ for $\operatorname{lgM}$.

\section{CONCLUSION}

This patient was initially diagnosed as having COVID-19 with radiological findings and rapid antibody test and it was learned that repeated PCR test was positive in the late period. The evaluation of laboratory tests together considering clinical compliance is guiding in the early differential diagnosis of COVID-19.

\section{Ethics}

Informed Consent: Written consent was obtained from the patient for this case report.

Peer-review: Internally peer-reviewed.

\section{Authorship Contributions}

Surgical and Medical Practices: M.T.Y., K.H., S.K., M.O., Concept: M.T.Y., Design: M.T.Y., Data Collection or Processing: M.T.Y., K.H., S.K. D.K., Analysis or Interpretation: M.T.Y., K.H., S.K., Literature Search: M.T.Y., Writing: M.T.Y., S.K.

Conflict of Interest: No conflict of interest was declared by the authors.

Financial Disclosure: The authors declared that this study received no financial support.

\section{REFERENCES}

1. Guan W, Ni Z, Hu Y, Liang W, Ou C, He J, et al. Clinical characteristics of Coronavirus Disease 2019 in China. N Engl J Med 2020;382:1708-20.

2. Lanza E, Muglia R, Bolengo I, Santonocito OG, Lisi C, Angelotti G, et al. Quantitative chest CT analysis in COVID-19 to predict the need for oxygenation support and intubation. Eur Radiol 2020. https://doi. org/10.1007/s00330-020-07013-2

3. T.C. Sağlık Bakanlığı, Halk Sağlığı Genel Müdürlüğü. COVID-19 (SARSCoV-2 Enfeksiyonu) Genel Bilgiler, Epidemiyoloji ve Tanı. Bilimsel Danıșma Kurulu Çalıșması. Serolojik testler, p 14-15. (29 Haziran 2020). Available from: URL: https://covid19.saglik.gov.tr/Eklenti/38597/0/ covid-19rehberigenelbilgilerepidemiyolojivetanipdf.pdf 